\title{
Review on Cissampelos Pareira \& Cyclea Peltata (Patha Dwaya) Phyto-Pharmacological Perspectives
}

\section{Review article}

\section{Suman Singh ${ }^{1^{*}}$, Nishteswar $\mathbf{K}^{2}$}

1. M.D. $2^{\text {nd }} \mathrm{yr}$ scholar, 2. Head of Department, Dravyaguna dept., I.P.G.T \&R.A, G.A.U., Jamnagar.

\begin{abstract}
Patha is a widely used drug in Ayurveda. Botanical source of the Laghupatha and Rajpatha are Cissampelos pareira and Cyclea peltata respectively, which belong to the Menispermaceae family. They contain many alkaloids like hayatine, hayatinine, hayatidine and other bisbenzylisoquinoline alkaloids, berberines etc. which are found to be responsible for its various activities like anti-inflammatory, analgesic, antihaemorrhagic, gastroprotective, antioxidant, cardioprotective etc. The present review study is an attempt to provide reported information on its phyto-constituents, and pharmacological activites.
\end{abstract}

Keywords: Laghupatha, Rajpatha, Cissampelos pareira, Cyclea peltata, alkaloids, Menispermaceae, Patha.

\section{Introduction:}

Cissampelos pareira Linn. belongs to the Menispermaceae family is a sub-erect or climbing herb, known as laghupatha in Indian traditional medicine.(1) There are 37 plant species worldwide distributed under this genus. Only one of them occurs in India.(2) A very variable, lofty, slender, dioecious, perennial climber, commonly distributed throughout tropical and sub-tropical IndiaHimachal Pradesh, Chota Nagpur, Bihar, West Bengal, Punjab, Rajasthan, particularly in the east of Aravalli, hilly forests of Marathwada, Konkan, Deccan, Tamilnadu.(3) Rootstock woody, perennial; leaves usually peltate or

*Corresponding Author:

Suman Singh
M.D. $2^{\text {nd }}$ yr scholar,
Dravyaguna dept.,
I.P.G.T \&R.A,G.A.U., Jamnagar
E-mail.address: snghsmn@gmail.com
Contact No.: 09510172204

orbicular-reniform or ovate-sub-reniform, with a truncate-cordate base, glabrous or hairy above, 3-12 cm across; flowers greenish yellow, male in axillary, fascicled, pilose cymes or panicles; female flower in 6-15 cm long pendulous racemes; drupes small, ovoid - subglobose or obovoid, compressed, scarlet red, hirsute; seeds horse - shoe shaped. The plant is common in orchards, hedges, parks and gardens on moist soils, either creeping or twining around other plants; also common on hilly tracts along watercourses. (4)

Cyclea peltata (Lam) Hook. F. \& Thomas also belongs to Menispermaceae family, which is known as Rajpatha in various parts of India. A much-branched, climbing shrub found throughout South and East India and in the Andaman and Nicobar Islands.(5) Roots tuberous; Leaves deltoid or ovate, acute, truncate or slightly sinuate at the base with rounded angles, mucronate, more or less hairy on the nerves and veins, margin often ciliate; 
flowers in axillary panicles. Male flowers subsessile, interruptedly spicate or collected into heads. Female flowers racemose, sepals oblong, glabrous. Petals orbicular, much shorter than the sepal; ovary pilose; berries drupaceous. (6)

\section{Materials \& method:}

Ayurvedic classics, lexicons and other compilatory treatises are reviewed for documenting the information about Patha. The published works on journals and information available on web pages are consulted to review about Patha in terms of phyto-pharmacological information.

\section{Phyto- constituents:}

\section{(A) Cissampelos pareira:}

Alkaloids, viz. hayatine $( \pm$ curine), hayatinine, hayatidine and other bisbenzylisoquinoline alkaloids, some non nitrogenous components, e.g., quercitol and sterol (root); cyclanoline chlorides, a non phenolic tertiary alkaloid (tetra hydroisoquinoline chromophone), alkaloids viz., seepeerine, berberine, cissampeline, pelosine (or berberine ), hayatin, hayatinin, $1-$ curine and $d-$ isochondrodendrine along with a saponin, quaternary ammonium bases, d-quercetol and sterol, a base with a dihydroisoquinoline nucleus, cycleamine, hayatinin (4"-0- methyl berberine ) and hayatidin $(++)-4 "$ - 0 - methyl berberine ), three water soluble bases viz., menismin iodine, cissamin chloride and pareirin, cissamine chloride, cissampareine, five unidentified tertiary alkaloids, (++)-4"-0methyl curine, tetrandrine (an alkaloid), dehydrodicentrine, dicentrine and insularine, bis (benzylisoquinoline), alkaloids viz., tetrandrinemono-N-Z'oxide, isochondodendrine and chondo curine and an alkaloids DL- curine dimethiodide (daijisong) (root and root bark); cycleanine, 1- berberine, hayatidin, hayatinin, hayatin and d- quercitol (leaves); tropoloisoquinoline alkaloids (plant).(7)

\section{(B) Cyclea peltata:}

The leaves of $C$. peltata are found to contain alkaloids such as cycleanine, berberine, hayatinin, hayatidin and hayatin. Root contains bisbenzylisoquinoline alkaloids, cycleapeltine, cycleadrine, cycleacuine, cycleanorine and cycleahomine chloride. (8)

Table 1: Ayurvedic classics and Nighantus have mentioned the following indications for Patha:

\begin{tabular}{|l|c|c|c|c|c|c|c|c|}
\hline \multicolumn{1}{|c|}{ Indications } & C.S & S.S & A.H & D.N & MP.N & R.N & K.N & B.N \\
\hline Aruchi (Anorexia) & + & + & - & - & - & - & - & - \\
\hline Arsha (Piles) & + & - & + & - & - & - & - & - \\
\hline Atisara (Diarrhoea) & - & + & + & + & + & + & + & + \\
\hline Apasmara (Epilepsy) & + & + & - & - & - & - & - & - \\
\hline Chhardi (Vomiting) & - & - & - & + & + & - & - & + \\
\hline Daha (Feeling of burning sensation) & - & - & - & - & + & + & + & + \\
\hline Grahani (Malabsorption syndrome) & + & + & + & - & - & - & - & - \\
\hline Granthi artava & - & - & + & - & - & - & - & - \\
\hline Gulma(Abdominal tumor) & - & - & - & - & + & - & + & + \\
\hline Haleemaka (Chlorosis) & + & - & - & - & - & - & - & - \\
\hline Hridroga (Disease of the heart) & - & + & - & + & + & - & + & + \\
\hline Jwara (Pyrexia) & + & + & + & + & + & + & + & + \\
\hline Kamala (Jaundice) & + & + & + & - & - & - & - & - \\
\hline Kandu (Pruritis) & + & + & - & + & + & - & + & + \\
\hline Kaphajavyadhi (Disorders of kapha) & - & + & - & - & - & - & + & - \\
\hline
\end{tabular}




\begin{tabular}{|l|c|c|c|c|c|c|c|c|}
\hline Kasa (Cough) & + & + & + & - & - & - & - & - \\
\hline Krimi (Diseases due to parasites) & + & + & + & - & + & - & + & + \\
\hline Kushta (Skin diseases) & + & + & + & + & + & - & + & + \\
\hline Pandu (Anaemia) & + & + & - & - & - & - & - & - \\
\hline Pleeha (Splenomegaly) & + & + & - & - & - & - & - & - \\
\hline Prameha (Diabetes) & + & + & - & - & - & - & + & - \\
\hline Pravahika (Dysentery) & + & - & + & - & - & - & - & - \\
\hline Raktapitta (Haemorrhagic diathesis) & + & - & - & - & - & - & - & - \\
\hline Shoola (Pain disorders) & - & - & - & + & + & + & + & + \\
\hline Swasa (Dyspnoea) & + & + & + & - & + & - & + & + \\
\hline $\begin{array}{l}\text { Stanya vikar (Disorders of breast } \\
\text { milk) }\end{array}$ & + & + & + & - & - & - & - & - \\
\hline Switra (Leucoderma) & + & + & + & - & - & - & - & - \\
\hline Udara (Enlargement of udara) & + & - & - & - & - & - & - & + \\
\hline Unmada (Insanity) & + & + & - & - & - & - & - & - \\
\hline Upadamsha (Veneral diseases) & + & + & - & - & - & - & - & - \\
\hline Visha (Poisons) & + & + & - & + & + & - & + & + \\
\hline Vrana (Ulcers) & - & + & + & - & + & - & + & + \\
\hline
\end{tabular}

(C.S- Charak Samhita, S.S-Sushruta Samhita, A.H- Ashtanga Hridya, D.N- Dhanvantri nighantu, MD.N- Madanpal nighantu, R.N- Raj nighantu, K.N- Kaiydev nighantu, B.N- Bhavprakash nighantu)

\section{Research Studies:}

\section{(A) Cissampelos pareira - Toxicity:}

In the acute and subacute toxicity test, oral administration of $C$. pareira did not produced any changes in behaviour and physiological activities on experimental animals. Biochemical and hematological analysis did not show any changes. (Amresh et al., 2008)

\section{Antinociceptive and anti-arthritic activity:}

$50 \%$ aqueous ethanolic extract of roots of $C$. pareira at the dose levels of $100-400 \mathrm{mg} / \mathrm{kg}$ exhibited significant resistance against mechanical pain in analgesymeter induced pain in mice. Study also suggested that dose dependent significant protective effect of plant against complete Freund's adjuvant induced arthritis. (9)

\section{Anti-inflammatory activity:}

Ethanolic extract of $C$. pareira aerial parts exhibited significant and dose dependent anti-inflammatory activity in the carrageenan test, which has been confirmed by the arachidonic acid test (Amresh et al., 2007). Ethanolic extract $(50 \%)$ of Cissampelos pareira roots (CPE) in acute, subacute and chronic models of inflammation exhibited significant antiinflammatory activity (10). The methanolic extract showed significant anti-inflammatory activity similar to ibuprofen and indomethacin. (11)

\section{Anti-fertility activity:}

Oral administration of $C$. pareira leaf extract altered the estrous cycle pattern, prolonged the length of estrous cycle with significant increase in the duration of diestrus stage and reduced significantly the number of litters in female albino mice. Plant extracts altered release of gonadotropin (LH, FSH and prolactin) and estradiol secretion. The results indicated the antifertility effect of C. pareira leaf extract in female albino mice. (12) Hydro-alcoholic extract showed significant anti-fertility activity on male Albino-Rats. (13) 


\section{Antioxidant activity:}

Ethanolic extract of $C$. pareira roots showed significant antioxidant activity in the 1,1-diphenyl-2picrylhydrazyl assay. It was found to significantly scavenge superoxide, hydrogen peroxide, hydroxyl radicals, and nitric oxide at a dose regimen of 50 to 400 $\mu \mathrm{g} / \mathrm{kg}$ in vitro. $C$. pareira extract exhibit a potent protective activity in an acute oxidative tissue injury animal model: benzo (a) pyrene induced gastric toxicity in mice in vivo. (14)

\section{Chemo-preventive effects:}

With administration of $C$. pareira root's extract protective effect against benzo (a) pyrene [B(a)P]-induced gastric cancer was found in mice, and the tumor incidence was reduced. The modulatory effect was also found on carcinogen metabolizing phase I and phase II enzymes, antioxidant enzymes, glutathione content, lactate dehydrogenase, and lipid peroxidation in liver study. (15)

\section{Anti-hemorrhagic effects:}

Aqueous extract of C. pareira leaves and venom were injected in the skin of mice, and it was found that aqueous extract produced anti-hemorrhagic activity. On the other hand, experiments regarding the anti-proteolytic activity were conducted observing the effect on casein in a test tube or on biotinylated casein in a microplate. None of the two procedures was able to show any inhibitory activity. (16)

\section{Gastroprotective effects:}

Ethanolic extract of roots showed a dose-dependent, ulcer-protective effect in various acute and chronic ulcers. $C$. pareira significantly improved the defense factors as total hexose and sialic acid while significantly reducing the ulcer index in the lipid peroxidase product malondialdehyde in ethanol-induced ulcers. (17)

\section{Cardioprotective effect:}

Ethanolic extract of $C$. pareira roots attenuated isoproterenol-induced cardiac dysfunction, and it might be due to ameliorates calcineurin activity and free radical formation, and by augmentation of antioxidant enzymatic activities. (18)

\section{Anti-diarrhoeal activity:}

The hydro-ethanolic extract of $C$. pareira exhibited a dose dependent decrease in the total number of faecal droppings and 29.2-60.0\% inhibition in castor oil-induced diarrhoea. It reduced intestinal fluid accumulation (26.0-59.0\%) and gastrointestinal transit. (19)

\section{Hepato-protective effect:}

Hydro alcoholic extract showed protective action against hepatotoxicity caused by anti-tuberculosis drugs on wistar albino rats (20). Hydro-alcoholic extract of roots exhibited significant hepatoprotective action against $\mathrm{CCl} 4$ induced hepatotoxicity. (21)

\section{Memory enhancing activity:}

Elevated plus maze and passive avoidance paradigm study conducted in mice exhibited memory enhancing activity of C.pariera. (22)

\section{Anti-hyperglycemic activity:}

The methanolic extract of root showed dose dependent significant antihyperglycemic activity in streptozotocininduced diabetic rats. (23)

\section{Antioxidant and immunomodulatory activity: \\ Roots alkaloidal fraction possesses strong antioxidant activity by scavenging the stable free radical DPPH, superoxide ion and inhibiting lipid peroxidation in rat liver homogenate induced by iron/ADP/Ascorbate complex.}


Fraction also had significant immunosuppressive activity at lower doses. (24)

\section{(B) Cyclea peltata:}

\section{Anti oxidant activity:}

C. peltata roots are reported to contain tetrandrine, a bisbenzylisoquinoline dioxine alkaloid is well known for its antioxidant activity (Rastogi \& Mehrotra, 1999; Ng et al., 2006). The protective effect of leaf on cisplatin-induced nephrotoxicity and oxidative damage has been reported by ameliorate the oxidative stress parameters. (25) (26)

\section{Anti-Lithiasis effects:}

The root extract reduced the lithiasis confirmed by the reduced level of urinary oxalate and calcium in ethylene glycol induced lithiasis in rats. (27)

\section{Anti-hyperlipidemic effects:}

The ethanolic extract reduced the total cholesterol, LDL cholesterol and triglycerides and increased the HDL cholesterol in hypercholesterolemia induced rats. (28)

\section{Anti-diabetic effect:}

Aqueous extract significantly decreased both the fasting and postprandial blood glucose of type 2 diabetic rats and enhanced insulin levels in the diabetic rats. (29)

\section{Hepatoprotective effects:}

Pre-treatment with $C$. peltata $(250, \quad 500 \mathrm{mg} / \mathrm{kg})$ caused significant reduction of liver transaminases in the hepatotoxin treated rats, almost comparable to the Silymarin $(100 \mathrm{mg} / \mathrm{kg})$ treated groups. The study showed that drug significantly inhibited the liver MDA levels and attenuated the liver GSH levels of ethyl alcohol treated rats. (30)

\section{Gastric anti-secretory and anti-ulcer activities:}

The ethanolic extract of Cyclea peltata roots showed significant antisecretory activity by decreasing pepsin secretion, gastric juice volume and acid output in pylorus-ligated rats. Further, it showed significant gastroprotective effects on the stomach wall of ethanol or ethanol and indomethacin treated rats by decreasing malondialdehyde level, increasing the gastric wall mucus and nonprotein sulfahydryl groups. (31)

\section{Anti-bacterial activity:}

Methanolic extract of whole plant of $C$. peltata had higher inhibitory action against Staphylococcus aureus, Streptococcus haemolyticus, Klebsiella pneumonia and Proteus vulgaris while Acetone extract of plant showed maximum inhibitory action against Klebsiella pneumonia and Streptococcus haemolyticus. (32)

Another research work has been carried out to explore the potential of C.peltata against the bacteria.(33) Studies have reported that the methnolic extract of C.peltata exhibited significant antibacterial activity against S. pyogenes, P. vulgaris and E. coli and the hexane extract of this plant exhibited the same potential against $P$. vulgaris and $P$. mirabilis. (34)

\section{Anti-diuretic activity:}

The ethanolic and petroleum ether extracts of $C$. peltata were studied for diuretic activity in wistar rats using Lipschitz et al. method. (35)(36) The diuretic effect of ethanolic extract was significantly higher than that of petroleum extract. (37) 
Table 2: Research studies carried out on $C$.pareira and $C$.peltata can be summarized as given under

\begin{tabular}{|c|c|c|c|}
\hline $\begin{array}{c}\text { Name of the } \\
\text { plant }\end{array}$ & Activities & Extract & Part used \\
\hline 1. C. pareira & $\begin{array}{l}\text { a. Antioxidant } \\
\text { b. Antifertility } \\
\text { c. Chemopreventive } \\
\text { d. Anti-haemorrhagic } \\
\text { e.Antinociceptive \& } \\
\text { Antiarthritic } \\
\text { f. Anti-inflammatory } \\
\text { g. Gastroprotective } \\
\text { h. Cardioprotective } \\
\text { i. Anti-diarrhoeal } \\
\text { j. Hepatoprotective } \\
\text { k. Memory enhancing } \\
\text { 1. Anti-hyperglycemic }\end{array}$ & $\begin{array}{l}\text { Ethanolic } \\
\text { Hydro-alcoholic } \\
\text { Hydro-alcoholic } \\
\text { Aqueous } \\
\text { Ethanolic } \\
\text { Ethanolic } \\
\text { Ethanolic } \\
\text { Ethanolic } \\
\text { Ethanolic } \\
\text { Hydro-alcoholic } \\
\text { Hydro-alcoholic } \\
\text { Methanol }\end{array}$ & $\begin{array}{l}\text { Root } \\
\text { Leaves } \\
\text { Root } \\
\text { Leaves } \\
\text { Root } \\
\text { Aerial part } \\
\text { Root } \\
\text { Root } \\
\text { Root } \\
\text { Root } \\
\text { Root } \\
\text { Root }\end{array}$ \\
\hline 2. C. peltata & $\begin{array}{l}\text { a. Antioxidant } \\
\text { b. Anti-lithiasis } \\
\text { c. Anti-hyperlipidemic } \\
\text { d. Anti-diabetic } \\
\text { e. Hepatoprotective } \\
\text { f. Gastric antisecretory \& } \\
\text { anti-ulcer } \\
\text { g. Anti-bacterial } \\
\text { h. Anti-diuretic }\end{array}$ & $\begin{array}{l}- \\
- \\
\text { Ethanolic extract } \\
\text { Aqueous extract } \\
- \\
\text { Ethanolic } \\
\text { Ethanolic } \\
\text { Ethanolic \& } \\
\text { petroleum }\end{array}$ & $\begin{array}{l}\text { Leaf } \\
\text { Root } \\
- \\
\text { Root } \\
- \\
\text { Root } \\
\text { Whole plant } \\
\text { Leaves }\end{array}$ \\
\hline
\end{tabular}

\section{Conclusion:}

Patha is a well reputed drug quoted in the most of the ancient ayurvedic classics like Charak samhita (1000BC), Sushruta samhita (1000BC) and Ashtangahridya (6AD). The most of the ayurvedic compendia documented during medieval India have quoted several single and compound formulations consisting of Patha. While going through Samhitas and nighantus most of common indications found are for patha are jwara, atisara, kandu, kustha, shoola, swasa, vrana, visha, daha, hridroga. Research studies provided scientific validation for certain activities like anti-inflammatory, antinociceptive, antidiarrhoeal, antiarthritic, hepatoprotective, memory-enhancing, antihyperglycemic, antifertility, antiseptic, anti-haemorrhagic, anti- oxidant, immunomodulatory, chemoprotective, etc. The review made from various perspectives clearly indicates that Patha is an indispensible drug of Ayurvedic physician's armamentarium.

\section{References:}

1. Vaidya GB, Adarsha Nighantu, $2^{\text {nd }}$ ed., vol. 1. Chaukhambha Bharti Academy Publications, 1998:153

2. Singh AP, Gupta A, Dravyaguna Vijnana, New Delhi, Chaukhambha orientalia, 2005:29-30

3. Anonymous, Database on Medicinal Plants used in Ayurveda, vol 2, New Delhi, CCRAS, Dept of HFW, Reprint 2005: 438

4. Anonymous, The Wealth of India, Raw Materials vol.-3., New Delhi, Council of scientific \& Industrial Research publication, 1992: 591 
5. Anonymous, The Wealth of India(First supplement series), Raw Materials vol.-2., New Delhi, Council of scientific \& Industrial Research publication, 2004: 319

6. Theodore cooke, The Flora of the presidency of Bombay, vol 1, Dehradun, M/S Bishen singh mahendra pal singh, pg no. 24

7. Anonymous, Database on Medicinal Plants used in Ayurveda, vol 2, New Delhi, CCRAS, Dept of HFW, Reprint 2005: 438

8. Kupchan SM, Liepa AJ , Baxter RL, Hintz HP. New and related artifacts from Cyclea peltata. J Org Chem. 1978;38:1846-7.

9. G Amresh, PN Singh, CV Rao, Antinociceptive and antiarthritic activity of Cissampelos pareira roots - Journal of ethnopharmacology, 2007, 111: 531-536

10. G. Amresh, G.D. Reddy, Ch.V. Rao, P.N. Singh, Evaluation of antiinflammatory activity of Cissampelos pareira root in rats, J Ethnopharmacol.2007 Apr 4;110(3):526-31.

11. Gourab Saha, Pankaja Senapati, Narahari Sahu, Anti-inflammatory activity of Methanolic extract of Root of Cissampelos pareira on Carragenin induced rat paw edema, PHARMATUTOR-ART-1324

12. Ganguly M, Borthakur M, Devi N, Mahanta R. Antifertility activity of the methanolic leaf extract of Cissampelos pareira in female albino rats. J. Ethnopharmacol 2007;111:688-91.

13. Harisha B, Antifertility activity of Hydro - alcoholic extract of Cissampelos pareira Linn. On male Albino rats, IJPRD 2011; vol 3(12): 2012 (83-97)

14. Amresh G, Rao CV, Singh PN. Antioxidant activity of Cissampelos pareira on benzo (a) pyrene-induced mucosal injury in mice. Nut. Res.2007;27:625-32.
15. Amresh G, Rao Ch V, and Singh PN. Evaluation of Cissampelos pareira against gastric cancer and enzymes associated with carcinogen metabolism. Pharm. Biol., 2007;45:595-603

16. Badilla B, Chaves F, Jimenez S. Effects of an extract of Cissampelos pareira on the hemorrhagic and proteolytic activities from Bothrops asper venom. Pharmacog. Mag 2008; 4:27-31.

17. G. Amresh, Hussain Zeashan, Ram Ji Gupta, Ravi Kant, Chandana Venkateswara Rao, Paras Nath Singh. Gastroprotective effects of ethanolic extract from Cissampelos pareira in experimental animals. Journal of natural medicines, 2007: vol-61, Issue 3: $323-328$

18. Singh BK, Pillai KK, Kohli K, Haque SE. Effect of Cissampelos pareira root extract on isoproterenol-induced cardiac dysfunction, J Nat Med. 2013 Jan;67(1):51-60.

19. SM Kupchan, AC Patel, Tumor inhibitors VI. Cissampareine, new cytotoxic alkaloid from Cissampelos pareira. Cytotoxicity of bisbenzylisoquinoline alkaloids -J Pharm Sci. 1965 Apr; 54(4):580-3.

20. Sangameswaran Balakrishnan., Baljeet Singh Khurana. Hepatoprotective effect of hydroalcoholic extract of cissampelos pareira against rifampicin and isoniazid induced hepatotoxicity, Continental J. Pharmaceutical Sciences: 2012: 6 (1): 30 - 35,

21. Surendran S, Eswaran MB, Vijayakumar $\mathrm{M}$, Rao CV. In vitro and in vivo hepatoprotective activity of Cissampelos pareira against carbon-tetrachloride induced hepatic damage, Indian J Exp Biol. 2011 Dec;49(12):939-45

22. Pramodinee d. kulkarni. Memory enhancing activity of Cissampelos pariera in mice, International Journal 
of Pharmacy and Pharmaceutical Sciences, 2011; 3(2): 206.

23. K.Atchut Kumar. Antihyperglycemic activity of methanolic extract of Cissampelos pareira Linn roots on blood glucose levels of StreptozotocinInduced Diabetic rats, Journal of Pharmacy Research 2011,4(10),33993401

24. Bafna A, Mishra S. Antioxidant and immunomodulatory activity of the alkaloidal fraction of Cissampelos pareira Linn., Sci Pharm. 2010;78(1):21-31.

25. Vijayan FP, Rani VK, Vineesh VR, Sudha KS, Michael MM, Padikkala J. Protective effect of Cyclea peltata on Cisplatin induced nephrotoxicity and oxidative damage., J Basic Clin Physiol Pharmacol. 2007;50:812-4

26. K. K. Hullatti, U. V. Gopikrishna, and I. J. Kuppast, Phytochemical investigation and diuretic activity of Cyclea peltata leaf extracts, J Adv Pharm Technol Res. 2011; 2(4): 241244.

27. Christina AJM, Packialakshmi M., Nagarajan M, Kurian S., Modulatory effect of Cyclea peltata Lam on stone formation induced by Ethylene Glycol Treatment in rats., Methods Find Exp Clin Pharmacol. 2002; 24: 77-79.

28. Christina A, Christapher V, Packialakshmi M, Tobin GC, Preethi J, John C, Murugesh N. Effect of ethanolic extract of Cyclea peltata Lam on a hypercholesterolemic rat Model. Phcog Mag.2005; 1: 59-62.

29. Uysal KT, Wiesbrock SM, Marino MW, Hotamisligil GS., Protection from obesity-induced insulin resistance in mice lacking TNF alpha function., Nature 1997; 9: 610-614.

30. VJ Shine, PG Latha and S Shyamal., Hepatoprotective effects of Cyclea peltata (poir.) hook. f. \& thoms., in alcohol intoxicate rats, 20 Kerala Science Congress, Thiruvananthapuram, pp. $628-630$.

31. Shine VJ, Latha PG, Shyamal S, Suja SR, Anuja GI, Sini S, Pradeep S, Rajasekharan S., Gastric antisecretory and antiulcer activities of Cyclea peltata (Lam.) Hook. f. \& Thoms. in rats, $\mathrm{J}$ ethnopharmacol. 2009 Sep 7;125(2):350-5.

32. Jyothi Abraham and T. Dennis Thomas, Antibacterial activity of medicinal plant Cyclea peltata (Lam) Hooks \& Thoms. Asian Pacific Journal of Tropical Disease (2012)S280-S284

33. Hullatti KK, Sharada M.S., Antimicrobial activity of Cissampelos pareira, Cyclea peltata and Stephania japonica methanolic root extracts., Adv Pharmacol Toxicol 2007; 8:105108.

34. Rajendra DAR, Solomon J, Juststella WP, Johnson MA, Varaprasadham I. Antibacterial activity of selected ethnomedicinal plants from South India. Asian Pacific Journal of Tropical Medicine 2011; 4: 375- 378.

35. Mukharjee PK., Pharmacological screening of herbal drugs. In: Quality control of herbal drugs, 1st ed. New Delhi: Business Horizon Pharmaceutical Publisher, 2002:537.

36. Vogel HG. Drug discovery and evaluation; Pharmacological assays, 2nd ed. New York; Springer-Verlag.

37. Hullatti KK, Gopikrishna UV, Kuppast IJ. Phytochemical investigation and diuretic activity of Cyclea peltata leaf extracts. Journal of Advanced Pharmaceutical Technology \& Research 2011; 2: 241-244 